\title{
Teaching Reform and Practice of Project-Based Curriculum on Product Design
}

\author{
Lingyun Yang \\ Urban Vocational College of Sichuan \\ Chengdu, China
}

\begin{abstract}
This paper takes the curriculum on product design as an example. The methods of design and specific practices have been described in it. Based on the analysis of real cases, the author would like to provide some advice to the teaching reform of project-based curriculum on products design
\end{abstract}

Keywords—products design; project-based teaching; teaching reform

\section{INTRODUCTION}

Curriculum on product design is one of the core curriculums of industrial design major and product form design major in colleges and universities. What's more, it is an important way for students to raise their product design ability. ${ }^{[1]}$ Thus, the construction of scientific teaching system with its own characteristics is vitally important. Based on the practical experience on the product design courses, the author has explored the designing theory that makes the content of product design work as the carrier. The students' overall capacity such as the ability to analyze tasks, market research and analysis ability, creative expression capacity, professional ethics and professional quality should be trained. Moreover, the training course should base on the real conditions and meet the need of product designer post in enterprises. We should focus on the cultivation of students' logical thinking and good learning habit and make them have the ability to analyze and solve problems. In this case, the author has made exploration on teaching idea and teaching method of curriculum on product design.

\section{The Design Method of Project-BAsed CURRICULUM}

These curriculums focus on training the students to have the capacity to work as product designers. Based on the cooperation with product enterprises, the curriculums can be developed during the process of developing new products. This method is professional, practical and open [2]. We can adjust the teaching content and goal, according to the requirement of post in enterprises. Teaching process should be based on the project tasks; it should be also in line with the workflow process of designer in enterprises. Meanwhile, we should make the students as principal parts and highlight the training of their vocational ability. For the workflow of product design and development see "Table 1":

\section{Overall Design of ProJect-BASED CURRICUlum}

\section{A. The Selection of Teaching Content}

"Training through courses" should be changed into "project design" by the introduction of real projects from enterprises or design competition held by industrial enterprises. Only in this way can student avoid to "work behind closed doors" and "be an armchair strategist". While introducing a new project, we should make overall consideration on the following problems. First, whether it is closely related to this major and course. Second, if the completion time of project matches with the total class hours. Third, whether it is too difficult to students or not. Last, it there are enough hardware facilities such as practical training conditions and teachers for carrying out this project. We need to make full use of the advantages of regional economic development in Sichuan province. As Sichuan is the third furniture industry base in China, we should take the advantage of it and introduce new furniture product developing project.

\section{B. Design of Teaching Model----Task-Driven and Project- Oriented Teaching Process}

We should take the introduction of real projects from enterprises and design competition held by this industry as carrier; work task should be in teaching content and work process should be in teaching process. In this way, students can learn knowledge during practicing, vice versa. The integration of theory and practice can be realized.

During the teaching process, teaching activities are carried out according to the work tasks of project design. First of all, the teacher should introduce the project in detail in aspects like the analysis on project origin, requirement and market. Then, based on the completion time and total class hours, teachers are supposed to make a schedule of this curriculum. While, the students should search for information from journals and on the Internet, investigate the factory and sale shop, thus they can get clear knowledge of the mainstream of product design. In this case, they are able to put forward methods and draft the design scheme. After the reveal and approval of teachers, they can implement it and gain the design capacity by class designing and practicing both in campus and outside. For the detail, see "Table 2". 


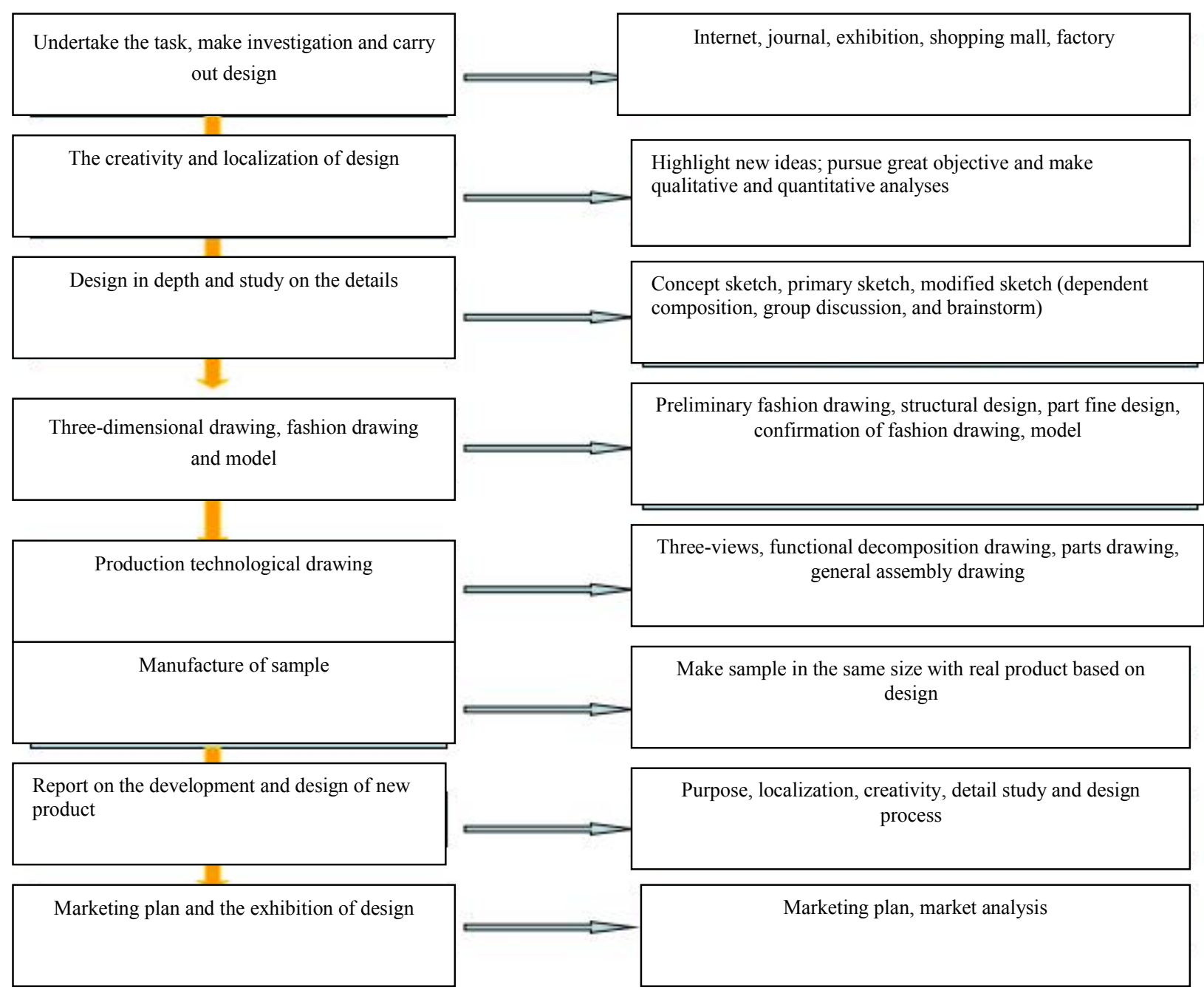

\section{Design of Teaching Method----Teachers Are Tutoring and Students Practicing}

Teacher staffs consist of school teachers and exports from enterprises. They are responsible for the tutoring of students in these curriculums. During the implementation of project, they should work together with the students design groups. Teachers from school should train the students in their product design skills, while the exports from enterprises are supposed to guide them in the connection of scheme with that in enterprise and teach them to make product models and real products. On this condition, students can both learn knowledge and practice during the implementation of project.

\section{Design of Teaching Environment----Carry out Dynamic Classroom}

Instead of teaching in the traditional multimedia

Item sources: school-level teaching reform item in Urban Vocational College of Sichuan: Teaching reform and Practice of project-based Curriculum on Artistic Design classrooms, we plan to carry out teaching process through dynamic classrooms. By the design of multiple teaching environments, for example, furniture store, furniture producing enterprise, multimedia classroom, in-campus practicing and training classroom, we can make dynamic classrooms. In this way, students can expend their vision of design; they will be more interested in learning as well. They can be equipped with vocational capacity that is in line with the designer post in enterprises through the observation, investigation, experience and practice. What's more, they can grasp the method to develop a new product and use their knowledge and skills in practice. [3] The teaching process of "product design and manufacture" can integrate class teaching, market investigation, model production and class questioning together. It may also help complete the design and manufacture of products systematically. 


\begin{tabular}{|c|c|c|c|}
\hline task & Content and Requirements & Training Goals & Methods \\
\hline $\begin{array}{c}\text { 1. Task } \\
\text { distributio } \\
\mathrm{n}\end{array}$ & $\begin{array}{l}\text { 1, Grasping the existing information, clearing } \\
\text { project tasks (for example, New furniture } \\
\text { development); } \\
\text { 2, Arranging contents according to the project } \\
\text { schedule; } \\
\text { 3, Completing assigned tasks According to the } \\
\text { groups. }\end{array}$ & $\begin{array}{l}\text { Clearing project tasks, setting up the } \\
\text { reasonable work schedule according to } \\
\text { the project tasks. }\end{array}$ & $\begin{array}{l}\text { Taught and } \\
\text { decomposed by } \\
\text { full-time and part- } \\
\text { time teachers }\end{array}$ \\
\hline $\begin{array}{l}\text { 2.Market } \\
\text { research }\end{array}$ & $\begin{array}{l}\text { 1, Task decomposition, case analysis and theory } \\
\text { teaching; } \\
\text { 2, Categories and characteristics of furniture; } \\
\text { 3, Field trip of furniture market and furniture } \\
\text { enterprises; } \\
\text { 4, Analysis of relevant cases. }\end{array}$ & $\begin{array}{l}\text { 1, Making targeted market research } \\
\text { according to the task } \\
\text { decomposition, understanding categories } \\
\text { and characteristics of furniture; } \\
\text { 2, Looking up furniture information } \\
\text { through the Internet at home and } \\
\text { abroad, and understanding it. }\end{array}$ & $\begin{array}{l}\text { Led and organized } \\
\text { by full-time and } \\
\text { part-time teachers }\end{array}$ \\
\hline $\begin{array}{l}\text { 3.Design } \\
\text { orientation } \\
\text { and design } \\
\text { originality } \\
\quad \text { of } \\
\text { Furniture }\end{array}$ & $\begin{array}{l}\text { 1,Mainstream and trend of domestic and foreign } \\
\text { furniture; } \\
\text { 2,Furniture features of different style; } \\
\text { 3、 Modeling design method of furniture; } \\
\text { 4、 Collection and selection of modeling factors; } \\
\text { 5,Expression of hand-painted idea sketching. }\end{array}$ & $\begin{array}{l}\text { 1, Understanding the mainstream of } \\
\text { living room furniture, as well as the } \\
\text { fashion trends according to the collected } \\
\text { data; } \\
\text { 2, Extract inspiration from the collected } \\
\text { information; } \\
\text { 3, Drawing idea sketching quickly。 }\end{array}$ & $\begin{array}{l}\text { Thoughts guided } \\
\text { by full-time and } \\
\text { part-time teachers }\end{array}$ \\
\hline $\begin{array}{l}\text { 4.Detail } \\
\text { treatment } \\
\text { and } \\
\text { detailed } \\
\text { design of } \\
\text { furniture }\end{array}$ & $\begin{array}{l}\text { 1, Selection and match of furniture materials; } \\
\text { 2, Selection and match of furniture color; } \\
\text { 3, Decoration design of furniture; } \\
\text { 4, Design of connected parts and the whole } \\
\text { furniture; } \\
\text { 5, Detailed treatment and emotional design of } \\
\text { furniture. }\end{array}$ & $\begin{array}{l}\text { 1, Matching appropriately according to } \\
\text { needs of clients and materials and } \\
\text { color; } \\
\text { 2, Furniture design conforming to } \\
\text { Ergonomics; } \\
\text { 3, Designing furniture structure } \\
\text { appropriately }\end{array}$ & $\begin{array}{l}\text { Guided by full- } \\
\text { time and part-time } \\
\text { teachers }\end{array}$ \\
\hline $\begin{array}{l}\text { 5.3D effect } \\
\text { figure and } \\
\text { flow } \\
\text { chart draw } \\
\quad \text { ing }\end{array}$ & $\begin{array}{l}\text { 1,Making model according to the sketch, paying } \\
\text { attention to the scale; } \\
\text { 2,Materials and matching effect of furniture; } \\
\text { 3,Drawing 2D、3D sketch. }\end{array}$ & $\begin{array}{l}\text { 1, Drawing standard and precise CAD } \\
\text { figure; } \\
\text { 2, 3D effect figure of high precision, } \\
\text { reasonable scale, materials conforming } \\
\text { to requirements. }\end{array}$ & $\begin{array}{l}\text { Guided by full- } \\
\text { time and part-time } \\
\text { teachers }\end{array}$ \\
\hline $\begin{array}{l}\text { 6.Model } \\
\text { making }\end{array}$ & $\begin{array}{l}\text { 1, Understanding own design accurately, making } \\
\text { conditions for furniture design; } \\
\text { 2, Understanding producing process of furniture; } \\
\text { 3, Making comparison between effect figure and } \\
\text { products, finding problems and differences, } \\
\text { putting forth revised proposals. }\end{array}$ & $\begin{array}{l}\text { 1, Making products independently or } \\
\text { assisting teachers to make products; } \\
\text { 2, Mastering making process of furniture. }\end{array}$ & $\begin{array}{l}\text { Guided by } \\
\text { examples of } \\
\text { enterprises } \\
\text { expert。 }\end{array}$ \\
\hline $\begin{array}{l}\text { 7.Review } \\
\text { and } \\
\text { evaluation } \\
\text { of } \\
\text { furniture }\end{array}$ & $\begin{array}{l}\text { 1, Evaluating design of yours and the others; } \\
\text { 2, Revising design according to proposals. }\end{array}$ & $\begin{array}{l}\text { 1, Evaluating furniture objectively; } \\
\text { 2, Revising design according to } \\
\text { proposals }\end{array}$ & $\begin{array}{l}\text { Evaluating by } \\
\text { students, full-time } \\
\text { and part-time } \\
\text { teacher together }\end{array}$ \\
\hline
\end{tabular}




\section{DeVelopment Process of Actual Cases}

Theme of the design: crossing the ancient and modern culture, leading Chinese fashion

Style of the design: modern Chinese style.

Structure: reality wood mortise-tenon structure.

Sketch of the design "Fig. 1" \& "Fig. 2":

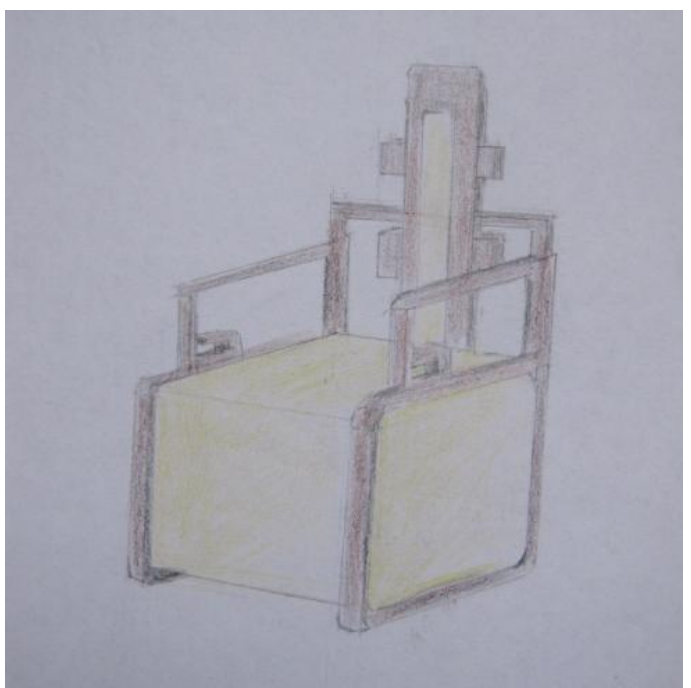

Fig. 1. Sketch of the design

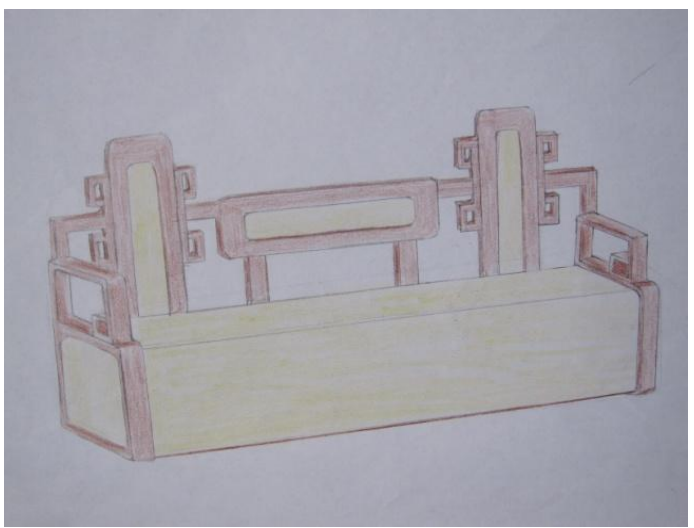

Fig. 2. Sketch of the design

Note for the design:

This design inspiration comes from Chinese traditional decorative patterns -- "fret". Modern people is more and more busy, creating comfortable life environment for consumers. Combining the Chinese traditional culture and modern furniture is the basic starting point of this design, combining dark ancient wood with China noble yellow in color, revealing the charm of classical culture and showing its sedate character at the same time. This product is used for common household lives, lounge, etc, creating a kind of both classic and the modern living environment striving to bring consumers a relaxed and comfortable life. 5":

Effect figures of different view "Fig. 3", "Fig. 4" \& "Fig.

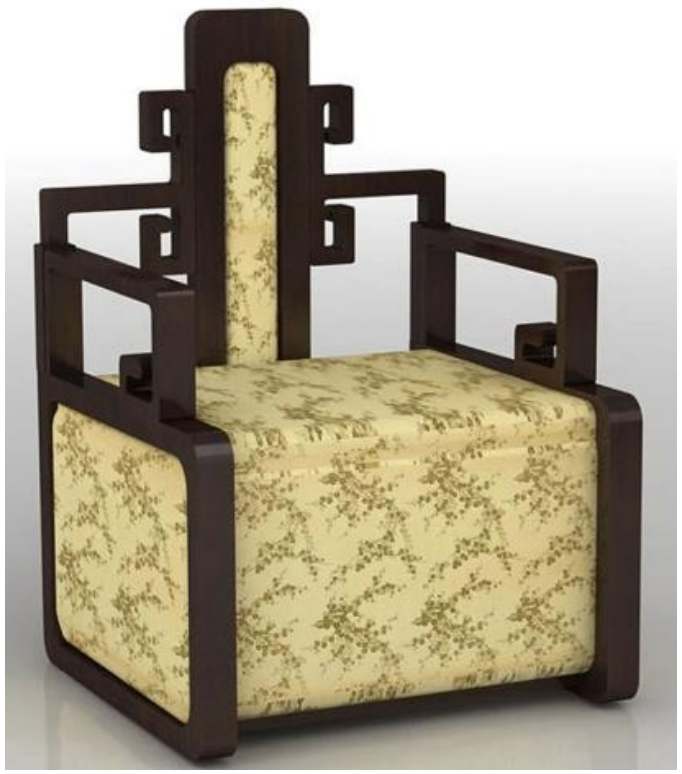

Fig. 3. Effect figures of different view

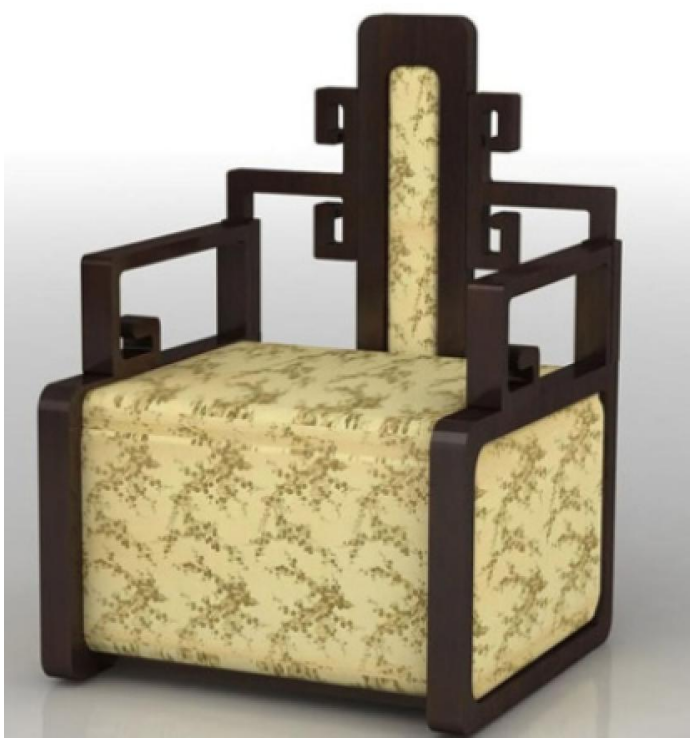

Fig. 4. Effect figures of different view

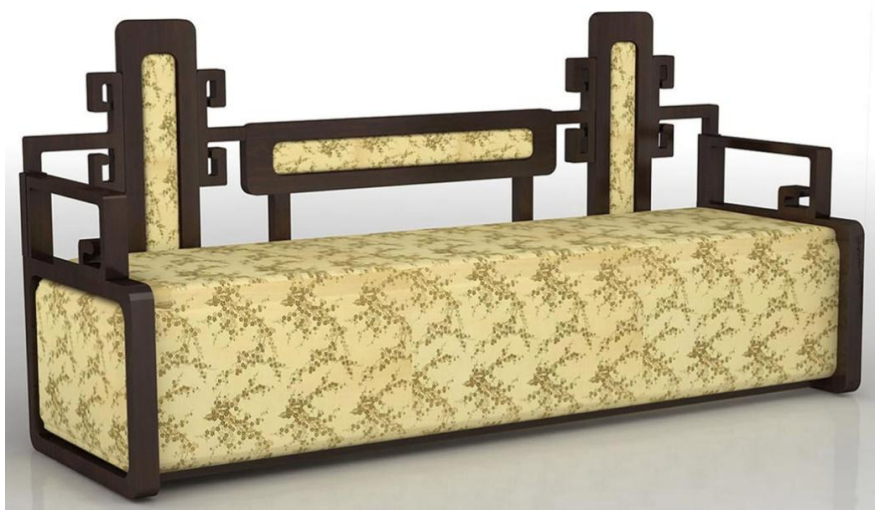

Fig. 5. Effect figures of different view 
Three Views figures "Fig. 6", "Fig. 7" \& "Fig. 8":

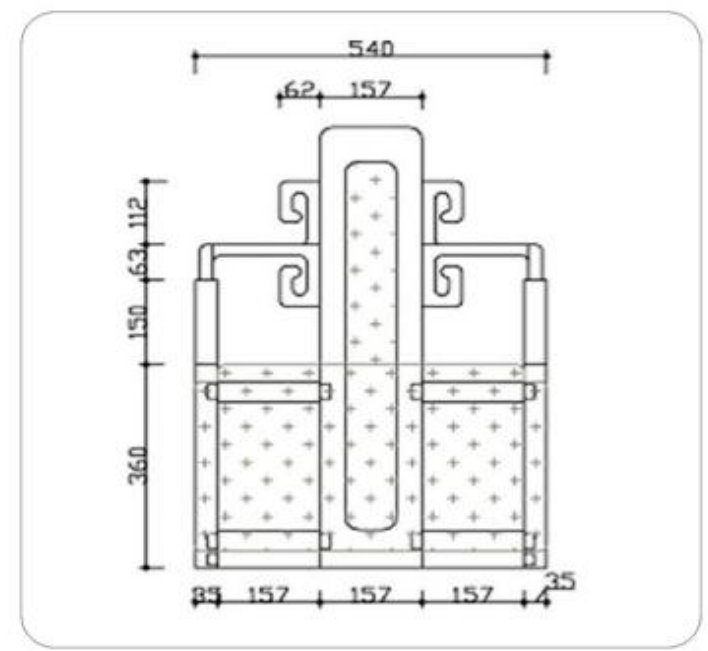

Fig. 6. Front view

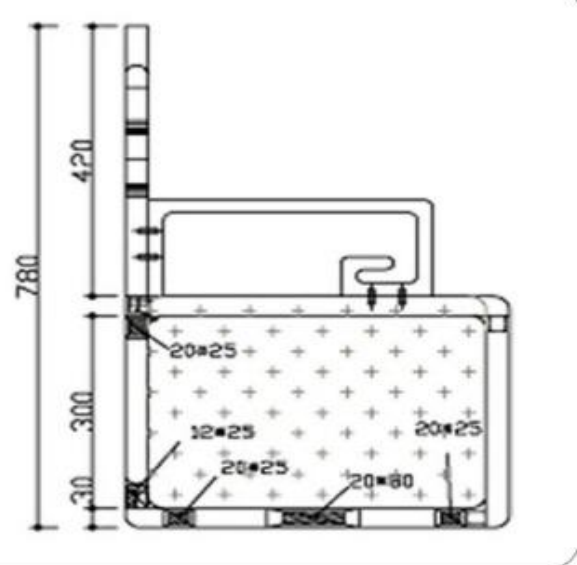

Fig. 7. Left view

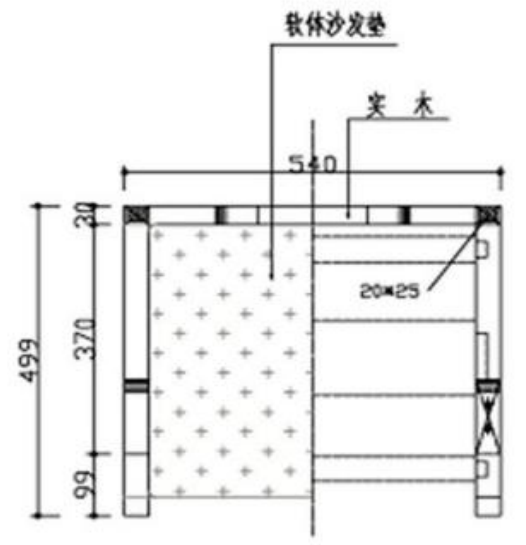

Fig. 8. Top view
Pictures of products "Fig. 9" \& "Fig. 10":

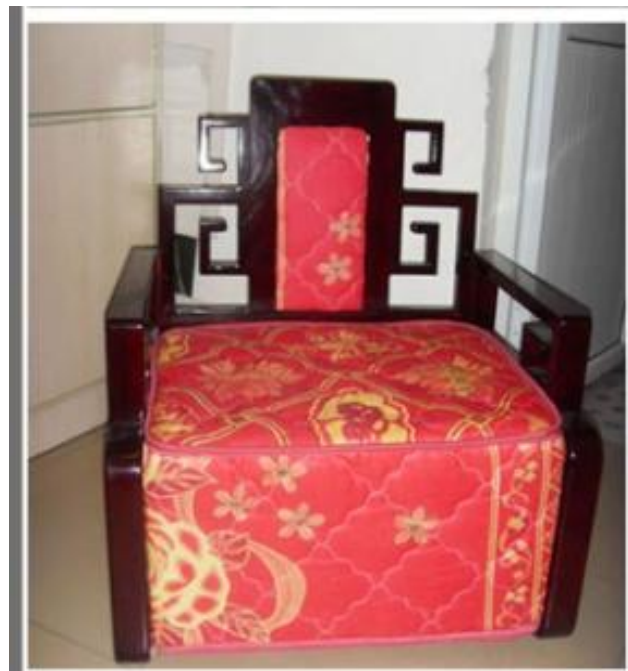

Fig. 9. Pictures of products

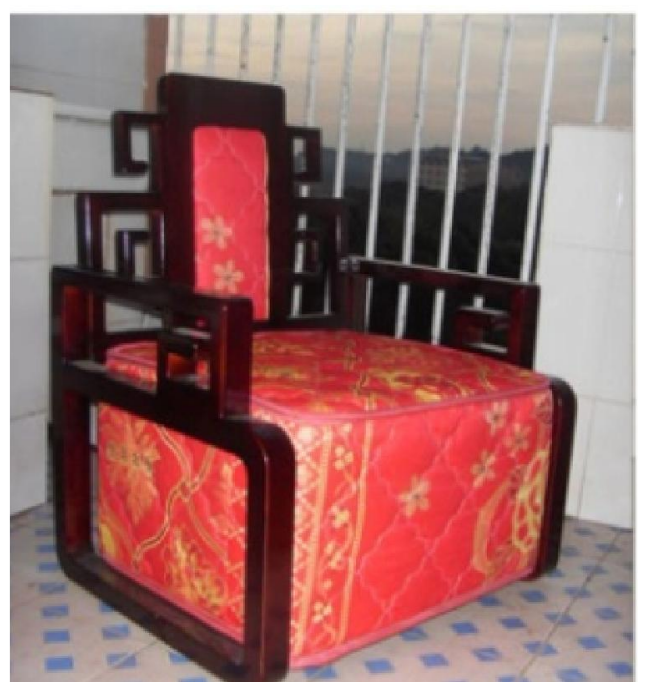

Fig. 10. Pictures of products

\section{Project Assessment of THE COURS}

Course assessment contents consist of abilities about design inspiration and sketch of different stages, note writing for design, propaganda board design, and model making, which aims at strengthening guidance and supervision of design process, knowing the study Schedule and accomplishment of students and forming a "teaching- learning -making- evaluating" pattern. In the process of completing the design, process assessment helps to promote independent learning of students, avoid passive learning phenomena such as copy and temporary assault.

Course assessment is conducted by leaders of student groups, enterprise personnel and teachers together to enhance the fairness of the assessment and motivate students to participate actively. The details of the assessment are as follows: 
TABLE III. STATEMENT OF ASSESSMENT

\begin{tabular}{|c|c|c|c|}
\hline Assessment & \multicolumn{3}{|c|}{ Detailed Grading } \\
\hline \multirow{3}{*}{$\begin{array}{l}\text { Originality } \\
\text { ( } 30 \text { points) }\end{array}$} & \multirow{3}{*}{$\begin{array}{c}\text { Originality is } \\
\text { unique and } \\
\text { novel }\end{array}$} & $\begin{array}{l}\text { Comparatively } \\
\text { good }\end{array}$ & $30-20$ points \\
\hline & & Common & $20-10$ points \\
\hline & & $\begin{array}{c}\text { Comparatively } \\
\text { bad }\end{array}$ & $10-0$ points \\
\hline \multirow{3}{*}{$\begin{array}{l}\text { Effect figure } \\
\text { and flow } \\
\text { chart drawing } \\
\text { (30 points) }\end{array}$} & \multirow{3}{*}{$\begin{array}{l}\text { Effect figure is } \\
\text { highly } \\
\text { precise, and } \\
\text { has good effect } \\
\text { of light, } \\
\text { materials and } \\
\text { color match } \\
\text { well; flow } \\
\text { chart drawing } \\
\text { is regular and } \\
\text { precise }\end{array}$} & $\begin{array}{l}\text { Comparatively } \\
\text { good }\end{array}$ & $30-20$ points \\
\hline & & Common & $20-10$ points \\
\hline & & $\begin{array}{c}\text { Comparatively } \\
\text { bad }\end{array}$ & $10-0$ points \\
\hline \multirow{3}{*}{$\begin{array}{c}\text { Note for } \\
\text { design } \\
\text { (15points) }\end{array}$} & \multirow{3}{*}{$\begin{array}{c}\text { Description is } \\
\text { brief and } \\
\text { accurate, design } \\
\text { conforms to the } \\
\text { theme }\end{array}$} & $\begin{array}{c}\text { Comparatively } \\
\text { good }\end{array}$ & $15-10$ points \\
\hline & & Common & $10-5$ points \\
\hline & & $\begin{array}{c}\text { Comparatively } \\
\text { bad }\end{array}$ & $5-0$ points \\
\hline \multirow{3}{*}{$\begin{array}{c}\text { Propaganda } \\
\text { board design } \\
\text { (10 points) }\end{array}$} & \multirow{3}{*}{$\begin{array}{l}\text { Structure and } \\
\text { composition are } \\
\text { appropriate, } \\
\text { form is } \\
\text { beautiful }\end{array}$} & $\begin{array}{c}\text { Comparatively } \\
\text { good }\end{array}$ & $10-7$ points \\
\hline & & Common & $7-4$ points \\
\hline & & $\begin{array}{c}\text { Comparatively } \\
\text { bad }\end{array}$ & 4-0 points \\
\hline \multirow{3}{*}{$\begin{array}{c}\text { Model making } \\
\text { (15 points) }\end{array}$} & \multirow{3}{*}{$\begin{array}{l}\text { Materials } \\
\text { match well, } \\
\text { products are } \\
\text { well-making }\end{array}$} & $\begin{array}{c}\text { Comparatively } \\
\text { good }\end{array}$ & $15-10$ points \\
\hline & & Common & $10-5$ points \\
\hline & & $\begin{array}{c}\text { Comparatively } \\
\text { bad }\end{array}$ & $5-0$ points \\
\hline Notes & no score & r same or simila & gnment \\
\hline
\end{tabular}

\section{CONCLUSION}

Project-based teaching method has broken the traditional teaching method of fixed courses, fixed classrooms and fixed teachers. It has created a "task-driven and project-based teaching model". Teaching method based on the cooperation of school, market and society and the integration of students, teachers and enterprises has been developed. Meanwhile, the teaching content is based on the working process, which can help raise the students' learning interests and make them be more initiative. It can also help train their comprehensive design ability. In this way, they will have independent thinking skills and teamwork spirit. This kind of curriculum has realized the transition from assignment to work and from work to product. By the practical reform of this kind of curriculum, we expect to start a discussion on other artistic design curriculums.

\section{REFERENCES}

[1] Zhao Jing, Li Yiting. Study on the Applied Teaching and Practice of Product Design Curriculums[J]. Journal of Hefei University.2012.5

[2] Huang Ji. The Exploration and Practice on the Curriculum Development of Accounting Major in Higher Vocational Colleges[J].Thesis in the Meeting of Vocational Teachers Forum in Wuxi.2008.

[3] Sun Liang. Research and Practice on the Training Model of Furniture Design Personnel in Higher Vocational Colleges under Industrial Upgrading[J].Furniture Interior Design.2011(7):59. 